\title{
Preoperative treatment of a parotid hemangioma with $100 \%$ ethyl alcohol
}

\author{
Ilteris Murat Emsen MD
}

\begin{abstract}
IM Emsen. Preoperative treatment of a parotid hemangioma with 100\% ethyl alcohol. Can J Plast Surg 2008;16(4):239240.

Hemangiomas are one of the most common childhood neoplasms, occurring in approximately $12 \%$ of infants younger than one year of age. The lesions typically appear shortly after birth, increase in size over the first year and characteristically regress over the next decade. Because hemangiomas can be visible during an important stage of a child's social development, numerous authors have pursued alternative treatment strategies to avoid or reduce this lengthy involution process. Unfortunately, no effective medical treatment has been reported for children with large, deforming hemangiomas of the parotid gland and overlying cheek. In the present case, a patient with a large parotid hemangioma was treated preoperatively with an intralesional injection of $100 \%$ ethyl alcohol solution to reduce the size of the mass. The mass was removed 28 days later with no major postoperative complications.
\end{abstract}

Key Words: Ethyl alcohol; Hemangioma; Injection

\section{Le traitement préopératoire d'un hémangiome parotidien à l'aide d'alcool éthylique $100 \%$}

Les hémangiomes font partie des néoplasmes les plus courants chez l'enfant. On les observe chez environ $12 \%$ des nourrissons de moins d'un an. D'ordinaire, les lésions se manifestent peu après la naissance, grossissent pendant la première année et régressent au cours des dix années suivantes. Puisque les hémangiomes peuvent être visibles pendant une phase importante du développement social de l'enfant, de nombreux auteurs ont recouru à des stratégies de traitement pour éviter ou raccourcir ce long processus d'involution. Malheureusement, on n'a déclaré aucun traitement médical efficace pour les enfants présentant un gros hémangiome déformant de la parotide et de la joue sus-jacente. Dans le présent cas, un patient ayant un gros hémangiome parotidien a subi un traitement préopératoire par injection d'une solution d'alcool éthylique $100 \%$ dans la lésion afin de réduire la dimension de la masse. On a procédé à l'ablation de la masse 28 jours plus tard, sans complication postopératoire majeure.
$\mathrm{H}^{2}$ emangiomas are one of the most common childhood neoplasms, occurring in approximately $12 \%$ of infants younger than one year of age. The lesions typically appear shortly after birth, increase in size over the first year and characteristically regress over the next decade. Because of their natural history, hemangiomas are often managed conservatively. Involution can take many years and ultimately may leave residual stigmas. Because hemangiomas can be visible during an important stage of a child's social development, numerous authors have pursued alternative treatment strategies to avoid or reduce this lengthy involution process. Unfortunately, no effective medical treatment has been reported for children with large, deforming hemangiomas of the parotid gland and overlying cheek. Steroids and interferon have been shown to be ineffective. Surgery and deep intraparenchymal laser treatment of parotid hemangiomas has generally been avoided because of potential facial nerve injury. Although cheek skin and underlying tissue may return to normal, there is often permanent residual telangiectasia, tissue laxity and fibrofatty fullness of the cheek following involution of large parotid hemangiomas (1).

In the present report, the authors present the case of a patient with a large parotid hemangioma who was treated preoperatively with an intralesional injection of $100 \%$ ethyl alcohol solution to reduce the size of the mass. The mass was removed 28 days later with no major postoperative complications.

\section{CASE PRESENTATION}

A seven-year-old boy was admitted to the Department of Plastic and Reconstructive Surgery, Numune State Hospital, Erzurum, Turkey, because of a mass on his right cheek. The mass had not been present at birth, but had appeared at one week of age as a pink-coloured patch on the right cheek, which became increasingly swollen. The patient had not previously been seen by a doctor. A large $13.5 \mathrm{~cm} \times 9.5 \mathrm{~cm}$ mass was observed on his right cheek. It was decided to inject the mass preoperatively with $100 \%$ ethyl alcohol solution $(15 \mathrm{~mL})$ under general anesthesia (Figure 1). Two hours before the injection, the patient was given acetominophen syrup orally to prevent postoperative hyperpyrexia or hyperthermia. Twentyeight days after the ethanol injection, the mass was surgically removed. There were no major postoperative complications, and only minor serous fluid leakage occurred for two days postoperatively. The patient had very satisfactory results one year after surgical resection (Figures $2 \mathrm{~A}$ and $2 \mathrm{~B}$ ).

\section{DISCUSSION}

Salivary gland tumours in the pediatric population are rare, and account for less than $1 \%$ of head and neck neoplasms. Of the salivary glands, the parotid is the most commonly affected site. In the first year of life, hemangiomas represent approximately $50 \%$ of parotid tumours. Parotid hemangiomas can become very large, resulting in severe facial deformity. Furthermore, the appearance of cheek skin and underlying tis-

Numune State Hospital, Department of Plastic and Reconstructive Surgery, Erzurum, Turkey

Correspondence and reprints: Dr I Emsen, K.Karabekir Mahallesi, Fuar Yolu, Mavi Site C Blok, No 25090, Erzurum, Turkey.

E-mail ilterisemsen@hotmail.com 


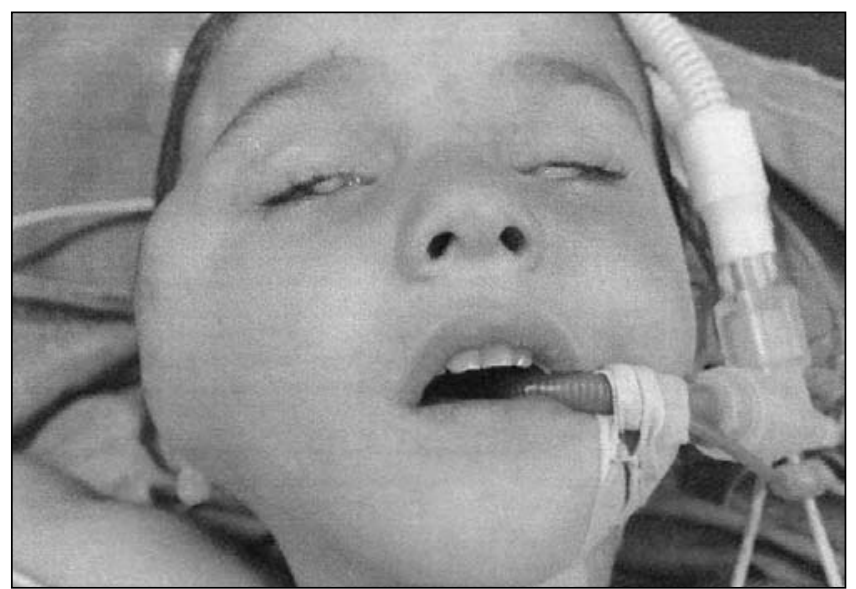

Figure 1) A seven-year-old boy with a large, right-sided parotid hemangioma, with mild cheek skin involvement, before surgical resection. At this time, $15 \mathrm{~mL}$ of $100 \%$ ethyl alcohol solution was injected intralesionally

sue may not return to normal after involution because of the residual effects of the tumour, such as loose skin, scarring and telangiectasias. Because the size of the hemangioma, location, sex and age at presentation do not influence the clinical course, it is difficult to predict which patients will have complete involution and which patients will have residual disfigurement (2,3). Parotid hemangiomas are usually evident on physical examination. These tumours can be confirmed by various diagnostic tools, such as ultrasonography, computed tomography and magnetic resonance imaging. In the present patient, the parotid hemangioma was diagnosed by clinical history and physical examination. Clinical diagnosis of a parotid hemangioma excluded the need for additional studies, because our management of these tumours would not be influenced by further studies. Because of the benign nature of most parotid hemangiomas, many authorities advocate conservative, nonoperative management, including steroids, interferon and compression therapy. In a retrospective review of 13 patients treated with oral steroids and interferon alpha-2a therapy, Blei et al (4) reported no improvement in parotid hemangioma size, suggesting that tumours in this location may be more resistant than those limited to skin and subcutaneous tissue. Systemic steroids and interferon should be used with caution in the pediatric population because of the risks of potential side effects $(4,5)$. Boon et al (6) studied 62 patients treated with corticosteroids and reported short-term complications, including cushingoid facies, personality changes, gastric irritations, fungal infections, and diminished growth and weight gain. The authors concluded, however, that most side effects were minor and transient, with no significant long-term sequelae. Intralesional alcohol injections have been shown to be a safe technique for vertebral hemangiomas in many studies (7); therefore, we decided to try this in a parotid hemangioma.

\section{CONCLUSIONS}

In the present study, our aim was to diminish the size of parotid hemangioma with $100 \%$ ethyl alcohol, with the intention of reducing the amount of bleeding at surgery and having better exposure of the facial nerve to prevent its injury.

ACKNOWLEDGEMENT: This case study was accepted and presented as a poster in ECSAPS 2006 Congress, September 9 and 10, in Northwood, London, United Kingdom.
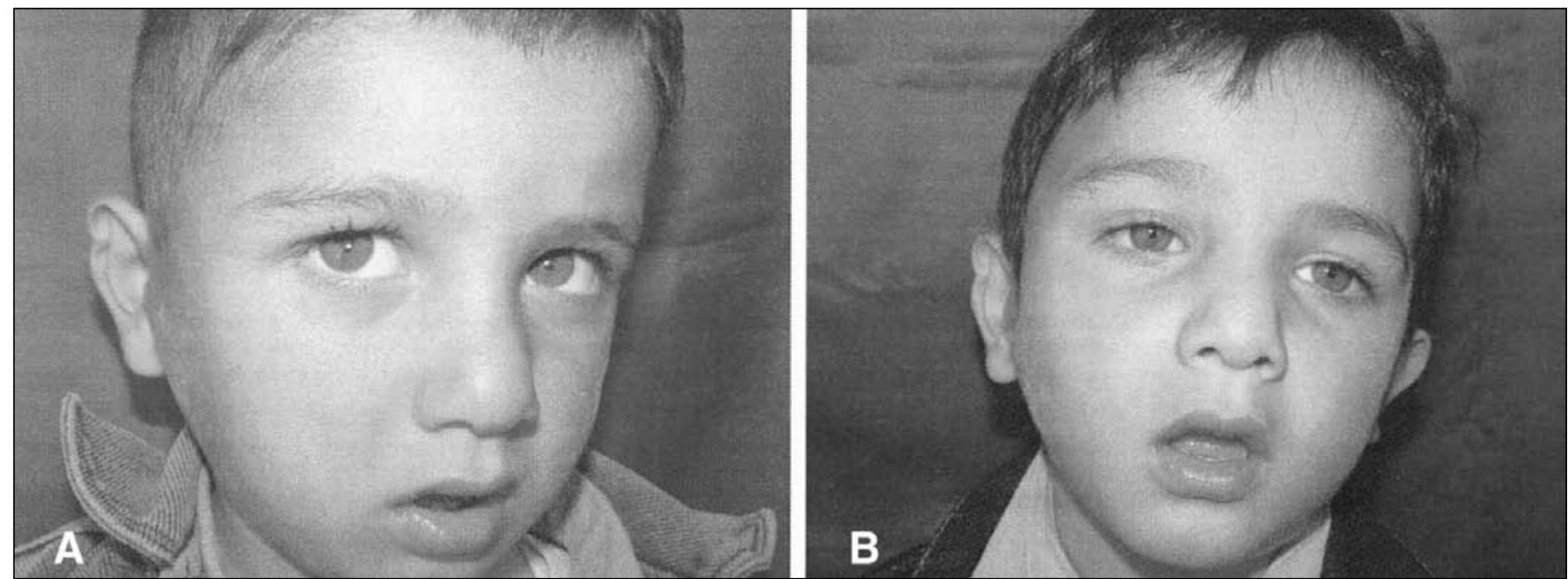

Figure 2) A and B Same child, after the ethyl alcohol injection, one year after surgical resection

\section{REFERENCES}

1. Reinisch JF, Kim RY, Harshbarger RJ, Meara JG. Surgical management of parotid hemangioma. Plast Reconstr Surg 2004;113:1940-8.

2. Bentz BG, Hughes CA, Lüdemann JP, Maddalozzo J. Masses of the salivary gland region in children. Arch Otolaryngol Head Neck Surg 2000;126:1435-9.

3. George CD, Ng YY, Hall-Craggs MA, Jones BM. Parotid haemangioma in infants: MR imaging at 1.5T. Pediatr Radiol 1991;21:483-5.

4. Blei F, Isakoff M, Deb G. The response of parotid hemangiomas to the use of systemic interferon alfa-2a or corticosteroids. Arch Otolaryngol Head Neck Surg 1997;123:841-4.

5. Gampper TJ, Morgan RF. Vascular anomalies: Hemangiomas. Plast Reconstr Surg 2002;110:572-85.

6. Boon LM, MacDonald DM, Mulliken JB. Complications of systemic corticosteroid therapy for problematic hemangioma. Plast Reconstr Surg 1999;104:1616-23.

7. Bas T, Aparisi F, Bas JL. Efficacy and safety of ethanol injections in 18 cases of vertebral hemangioma: A mean follow-up of 2 years. Spine 2001;26:1577-82. 